\title{
FINANCIAL DISTRESS: RASIO KEUANGAN DAN STRUKTUR KEPEMILIKAN PADA PERUSAHAAN NON-KEUANGAN
}

\author{
VALENTINA \\ TJHAI FUNG JIN \\ Sekolah Tinggi IImu Ekonomi Trisakti, Jl. Kyai Tapa No. 20, Grogol, Jakarta, Indonesia \\ valentina271298@gmail.com, fungjin@stietrisakti.ac.id
}

\begin{abstract}
The purpose of this research is to analyze if the factors in this research can influence the occurrence of financial distress. This research analyze about liquidity, leverage, profitability, firm performance, dividend policy, firm size, managerial ownership, and institutional ownership which to test how far they affected the occurrence of financial distress. Data for this research was taken from annual report of non financial companies listed in Indonesia Stock Exchange in period 2016 to 2018. This research has 49 companies that fulfilled the criteria as the final sample. Hypothesis in this research were tested by multiple linear regression analysis method. The results showed that profitabilty, firm performance, firm size, and managerial ownership that has an effect on financial distress. Besides, liquidity, leverage, dividend policy, and institutional ownership has no effect on financial distress.
\end{abstract}

Keywords: Financial distress, firm performance, dividend policy, firm size, managerial ownership, institutional ownership.

Abstrak: Tujuan penelitian ini adalah untuk menganalisis apakah faktor-faktor dalam penelitian dapat mempengaruhi terjadinya financial distress. Penelitian ini menggunakan likuiditas, leverage, profitabilitas, kinerja perusahaan, kebijakan dividen, ukuran perusahaan, kepemilikan manajerial, dan kepemilikan institusional untuk menguji seberapa besar pengaruhnya terhadap terjadinya financial distress. Data penelitian ini berasal dari laporan keuangan tahunan perusahaan non keuangan yang terdaftar di Bursa Efek Indonesia selama 3 tahun yaitu 2016 sampai 2018. Penelitian ini menggunakan 49 perusahaan yang memenuhi kriteria sebagai sampel akhir. Dalam menguji hipotesis, penelitian ini menggunakan metode analisis regresi linear berganda. Hasil penelitian ini menunjukkan bahwa profitabilitas, kinerja perusahaan, ukuran perusahaan, dan kepemilikan manajerial berpengaruh terhadap financial distress. Di samping itu, likuiditas, leverage, kebijakan dividen, dan kepemilikan institusional tidak berpengaruh terhadap financial distress.

Kata Kunci: Financial distress, kinerja perusahaan, kebijakan dividen, ukuran perusahaan, kepemilikan manajerial, kepemilikan institusional.

\section{PENDAHULUAN}

Perkembangan ekonomi dunia mengalami kemajuan yang sangat pesat dalam beberapa tahun terakhir ini. Hal ini dikarenakan semakin kuat dan meluasnya globalisasi di seluruh dunia. Perkembangan globalisasi juga berdampak negatif terhadap perekonomian dunia. Menurut Mawutor (2014), pada tahun 2008 terjadi krisis ekonomi global akibat bangkrutnya Lehman Brothers sebagai salah satu perusahaan finansial terbesar. Setelah 
krisis ekonomi yang terjadi pada tahun 2008, krisis ekonomi kembali melanda perekonomian global pada tahun 2015. China mengalami pelemahan dalam aktivitas investasi dan manufaktur sehingga berdampak terhadap kegiatan impor maupun ekspor.

Tak dapat dipungkiri, krisis ekonomi yang terjadi berdampak terhadap perekonomian Indonesia. Penyebabnya dikarenakan China merupakan salah satu negara pengimpor terbesar di Indonesia sehingga efek dari krisis ekonomi yang terjadi di China menyebabkan beberapa perusahaan di Indonesia mengalami delisting dari Bursa Efek Indonesia. Menurut Witiastuti dan Suryandari (2016) delisting merupakan suatu tindakan yang dilakukan oleh Bursa Efek Indonesia (BEI) yang menyebabkan entitas berkaitan tidak dapat melakukan transaksi jual beli saham di pasar saham maupun pasar modal.

Banyak faktor yang menjadi pertimbangan Bursa Efek Indonesia dalam melakukan delisting perusahaan, salah satunya seperti menurunnya kinerja perusahaan dan seberapa besar beban utang yang ditanggung perusahaan. Jika suatu perusahaan terus mengalami penurunan kinerja, dikhawatirkan akan terjadi kondisi financial distress yang berujung pada bangkrutnya perusahaan. Kebangkrutan merupakan hal yang wajib diwaspadai. Financial Distress dapat didefinisikan sebagai perusahaan yang memiliki kinerja yang buruk, produsen yang tidak efisien, masalah terkait utang yang tinggi, dan masalah terhadap arus kas perusahaan dikarenakan perusahaan kehilangan nilai pasarnya (Kazemian et al. 2017).

Salah satu contoh kasus financial distress yang terjadi di Indonesia adalah pailitnya perusahaan PT Sariwangi Agricultural Estate Agency dan PT Maskapai Perkebunan Indorub Sumber Wadung. Pada tanggal 16 Oktober 2018 Majelis Hakim Pengadilan Niaga Jakarta Pusat mengabulkan permohonan pembatalan perdamaian atau homologasi dari pemohon (PT Bank ICBC) dan menyatakan bahwa termohon 1 (Sariwangi) dan termohon 2 (Indorub) pailit dengan segala akibat hukumnya (Widiasmara dan Rahayu 2019). Total utang Sariwangi mencapai US\$ 20.505.166 atau setara dengan Rp.306.900.000.000 sedangkan PT Maskapai Perkebunan Indorub Sumber Wadung yang merupakan pabrik yang mengelola Sariwangi mempunyai total hutang yang mencapai Rp.4.907.082.191.

Berdasarkan uraian yang telah dijabarkan, maka tujuan penelitian ini adalah untuk mendapatkan bukti empiris bahwa likuiditas, leverage, profitabilitas, kinerja perusahaan, kebijakan dividen, ukuran perusahaan, kepemilikan manajerial, dan kepemilikan institusional mempengaruhi terjadinya financial distress.

\section{Teori Keagenan}

Menurut Octalianna dan Rahayuningsih (2013), teori keagenan adalah teori yang mencerminkan hubungan yang terjadi antara principal dan agent. Dalam hal ini, principal sebagai pemilik perusahaan dan agent sebagai manajer perusahaan yang diamanatkan oleh pemilik perusahaan untuk menjalankan kewajiban perusahaan sebaik-baiknya. Pihak agent mempunyai lebih banyak informasi mengenai internal perusahaan dibandingkan principal dikarenakan manajer mempunyai wewenang untuk mengontrol kegiatan internal perusahaan dalam mencapai keuntungan di masa depan. Hal ini menyebabkan munculnya istilah asymmetric information. Kondisi ini menimbulkan konflik keagenan. Menurut Octalianna dan Rahayuningsih (2013), konflik keagenan memiliki asumsi bahwa setiap pihak termotivasi dengan keinginannya untuk memaksimalkan kesejahterannya masingmasing.

Untuk menghindari terjadinya masalah keagenan, manajer memberikan laporan keuangan sebagai bentuk laporan pertanggungjawaban dan laporan kinerja 
perusahaan kepada pemegang saham setiap periodenya. Pemegang saham dapat melakukan pengambilan keputusan berdasarkan laporan keuangan yang diberikan oleh manajer. Laporan tersebut juga dapat dijadikan sebagai referensi keadaan perusahaan saat ini maupun cerminan keadaan perusahaan di masa depan.

\section{Financial Distress}

Witiastuti dan Suryandari (2016), menjelaskan bahwa financial distress adalah tahap penurunan kondisi keuangan yang terjadi pada perusahaan sebelum terjadinya kebangkrutan atau likuidasi. Suatu perusahaan dapat dikatakan mengalami financial distress saat laporan keuangan menunjukkan angka laba operasi, laba bersih dan nilai ekuitas menunjukkan angka negatif.

Financial distress dapat diatasi dengan cara menganalisis rasio keuangan. Perusahaan akan terhindar dari kesulitan keuangan ketika perusahaan tersebut berhasil menganalisis rasio-rasio tersebut karena secara langsung rasio-rasio tersebut menggambarkan kondisi perusahaan dan dapat digunakan oleh manajer sebagai alat pengambilan keputusan.

\section{Likuiditas}

Menurut Tamam dan Wibowo (2017), likuiditas adalah kemampuan suatu perusahaan dalam memenuhi kewajiban jangka pendeknya pada saat jatuh tempo. Menurut Kazemian et al. (2017), likuiditas adalah ukuran sejauh mana seseorang atau suatu organisasi mempunyai uang tunai untuk memenuhi kewajiban jangka pendek, atau aset lain yang dapat menggantikan uang tunai. Rasio likuiditas keuangan adalah alat yang biasanya digunakan untuk mengukur likuiditas. Likuiditas mempunyai fungsi dan manfaat tertentu bagi suatu perusahaan yaitu sebagai media dalam melakukan kegiatan perusahaan sehari-hari dan sebagai alat untuk mengantisipasi kebutuhan dana yang mendesak atau tiba-tiba.

Penelitian Kazemian et al. (2017), Masdupi et al. (2018), Dance dan Made (2019), dan Fahlevi dan Marlinah (2018) mempunyai hasil bahwa likuiditas berpengaruh terhadap terjadinya financial distress. Selain itu, Prasetyo dan Fachrurrozie (2016), Jaafar et al. (2018), dan Widarjo dan Setiawan (2009) mempunyai hasil bahwa likuiditas tidak berpengaruh terhadap terjadinya financial distress.

Berdasarkan penjelasan di atas, hipotesis yang diajukan adalah:

$\mathrm{H}_{1}$ Likuiditas mempengaruhi terjadinya financial distress.

\section{Leverage}

Menurut Fahmi (2010), leverage adalah rasio yang mengukur seberapa besar perusahaan dibiayai dengan utang. Penggunaan utang yang terlalu tinggi akan membahayakan perusahaan karena perusahaan akan masuk dalam kategori extreme leverage (hutang ekstrim). Menurut Lestari dan Dewi (2013), leverage adalah hasil dari adanya biaya dalam penggunakan pembiayaan untuk aset atau untuk menyejahterakan dan meningkatkan pemegang saham. Terlalu tingginya penggunaan hutang suatu perusahaan dapat memperburuk perekonomian suatu perusahaan.

Penelitian Kazemian et al. (2017), Dance dan Made (2019), Jaafar et al. (2018), dan Masdupi et al. (2018) mempunyai hasil bahwa leverage berpengaruh terhadap terjadinya financial distress. Selain itu, Saputri dan Asrori (2019), Finishtya (2019), Fahlevi dan Marlinah (2018), dan Widarjo dan Setiawan (2009) mempunyai hasil bahwa leverage tidak berpengaruh terhadap terjadinya financial distress. Berdasarkan penjelasan di atas, hipotesis yang diajukan adalah:

$\mathrm{H}_{2}$ Leverage mempengaruhi terjadinya financial distress.

\section{Profitabilitas}

Profitabilitas adalah rasio yang mengukur efektivitas manajemen secara keseluruhan yang ditujukan oleh besar kecilnya tingkat keuntungan yang diperoleh dalam hubungannya dengan penjualan maupun 
investasi (Fahmi 2010). Menurut Mafiroh dan Triyono (2016), profitabilitas menunjukkan seberapa efisien dan efektif suatu perusahaan dalam memanfaatkan dan menggunakan aset perusahaan dalam menghasilkan laba.

Penelitian Kazemian et al. (2017), Finishtya (2019), Masdupi et al. (2018), Jaafar et al. (2018), Dance dan Made (2019), dan Widarjo dan Setiawan (2009) mempunyai hasil bahwa profitabilitas berpengaruh terhadap terjadinya financial distress. Selain itu, Saputri dan Asrori (2019) dan Fahlevi dan Marlinah (2018) mempunyai hasil bahwa profitabilitas tidak berpengaruh terhadap terjadinya financial distress. Berdasarkan penjelasan di atas, hipotesis yang diajukan adalah:

$\mathrm{H}_{3}$ Profitabilitas mempengaruhi terjadinya financial distress.

\section{Kinerja Perusahaan}

Kazemian et al. (2017) mengemukakan bahwa kinerja perusahaan dapat diidentifikasi melalui data terintergrasi tunggal dan dominan menggunakan rasio keuangan sebagai pengukuran kinerja perusahaan. Kinerja perusahaan yang buruk juga dapat meningkatkan kemungkinan perusahaan berubah menjadi perusahaan yang tertekan secara finansial. Penelitian Kazemian et al. (2017), Bisogno dan De Luca (2012), dan Pindado dan Rodrigues (2005) mempunyai hasil bahwa kinerja perusahaan berpengaruh terhadap terjadinya financial distress. Berdasarkan penjelasan di atas, hipotesis yang diajukan adalah:

$\mathrm{H}_{4}$ Kinerja perusahaan mempengaruhi terjadinya financial distress.

\section{Kebijakan Dividen}

Menurut Permanasari (2017), kebijakan dividen adalah kebijakan yang ditetapkan oleh suatu perusahaan pada saat RUPS (Rapat Umum Pemegang Saham), apakah dividen akan didistribusikan kepada para pemegang saham atau dijadikan sebagai cadangan investasi untuk proyek di masa yang akan datang. Dividen adalah laba bersih perusahaan yang didistribusikan kepada pemegang saham secara proporsional sesuai dengan kepemilikan saham mereka di perusahaan.

Penelitian Kazemian et al. (2017) dan Dwijayanti (2010) mempunyai hasil bahwa kebijakan dividen berpengaruh terhadap terjadinya financial distress. Selain itu, Widhicahyono (2015) mempunyai hasil bahwa kebijakan dividen tidak berpengaruh terhadap terjadinya financial distress. Berdasarkan penjelasan di atas, hipotesis yang diajukan adalah:

$\mathrm{H}_{5}$ Kebijakan dividen mempengaruhi terjadinya financial distress.

\section{Ukuran Perusahaan}

Ukuran perusahaan adalah proses mengelompokkan perusahaan ke dalam beberapa kategori, diantaranya perusahaan besar, perusahaan sedang dan perusahaan kecil. Skala perusahaan merupakan ukuran yang dipakai untuk mengelompokkan perusahaan kedalam kategori tersebut. Rianti dan Winwinyadiati (2018) mengungkapkan bahwa ukuran perusahaan dapat diilustrasikan sebagai ukuran total aset yang dimiliki oleh perusahaan. Semakin besar perusahaan, maka semakin besar akses pendanaan yang dmiliki oleh perusahaan.

Penelitian Rianti dan Winwinyadiati (2018) mempunyai hasil bahwa ukuran perusahaan berpengaruh terhadap terjadinya financial distress. Selain itu, Sastriana dan Faud (2013), Prasetyo dan Fachrurrozie (2016), dan Jaafar et al. (2018) mempunyai hasil bahwa ukuran perusahaan tidak berpengaruh terhadap terjadinya financial distress.

Berdasarkan penjelasan di atas, hipotesis yang diajukan adalah:

$\mathrm{H}_{6}$ Ukuran perusahaan mempngaruhi terjadinya financial distress.

\section{Kepemilikan Manajerial}


Kepemilikan manajerial adalah suatu kondisi yang menunjukkan bahwa manajer memiliki saham di perusahaan atau manajer merupakan pemegang saham itu sendiri. Hal ini dapat dilihat melalui persentase kepemilikan oleh manajemen perusahaan dalam hal kepemilikan oleh dewan direksi dan dewan komisaris. Menurut Idarti dan Hasanah (2018), manajer sekaligus merangkap pemegang saham akan melakukan pekerjaan secara optimal dan maksimal. Manajemen selalu berusaha memenuhi dan meningkatkan kinerja dan nilai perusahaan.

Penelitian Maryam dan Yuyetta (2019) mempunyai hasil bahwa kepemilikan manajerial berpengaruh terhadpa terjadinya financial distress. Selain itu, Anggraini (2016), Ibrahim (2018), Prasetyo dan Fachrurrozie (2016), dan Sastriana dan Fuad (2013) mempunyai hasil bahwa kepemilikan manajerial tidak berpengaruh terhadap terjadinya financial distress.

Berdasarkan penjelasan di atas, hipotesis yang diajukan adalah:

$\mathrm{H}_{7}$ Kepemilikan manajerial mempngaruhi terjadinya financial distress.

\section{Kepemilikan Institusional}

Kepemilikan institusional adalah persentase saham yang dimiliki oleh suatu institusi dari total saham yang beredar. Kepemilikan institusional dapat mengurangi masalah keagenan karena pemegang saham institusional akan membantu mengawasi perusahaan sehingga manajemen tidak akan melakukan hal yang merugikan pemegang saham. Khurshid et al. (2018) menjelaskan bahwa kepemilikan institusional dapat digambarkan seperti mendistibusikan saham kepada pihak luar perusahaan. Dengan adanya pendistribusian saham kepada pihak luar dapat membantu mengurangi adanya konflik keagenan dalam perusahaan dan mengurangi biaya keagenan yang mungkin timbul di masa depan.

Penelitian Anggraini (2016), Ibrahim (2018), dan Maryam dan Yuyetta (2019) mempunyai hasil bahwa kepemilikan institusional berpengaruh terhadap terjadinya financial distress. Selain itu, Prasetyo dan Fachrurrozie (2016), dan Sastriana dan Faud (2013) mempunyai hasil bahwa kepemilikan institusional tidak berpengaruh terhadap terjadinya financial distress. Berdasarkan penjelasan di atas, hipotesis yang diajukan adalah:

$\mathrm{H}_{8} \quad$ Kepemilikan institusional mempengaruhi terjadinya financial distress.

\section{METODE PENELITIAN}

Obyek penelitian dalam penelitian ini adalah perusahaan non keuangan yang terdaftar di Bursa Efek Indonesia selama tahun 2016 sampai tahun 2018. Teknik pemilihan sampel dalam penelitian ini menggunakan purposive sampling, berikut tabel pemilihan sampel:

Tabel 1 Kriteria Pemilihan Sampel 


\begin{tabular}{|c|c|c|}
\hline Deskripsi Kriteria & $\begin{array}{c}\text { Jumlah } \\
\text { Perusahaan }\end{array}$ & $\begin{array}{l}\text { Jumlah } \\
\text { Data }\end{array}$ \\
\hline $\begin{array}{l}\text { Perusahaan non keuangan yang terdaftar di Bursa Efek } \\
\text { Indonesia selama tahun } 2015 \text { sampai } 2018 \text {. }\end{array}$ & 435 & 1305 \\
\hline $\begin{array}{l}\text { Perusahaan non keuangan yang tidak menerbitkan } \\
\text { laporan keuangan dengan tahun buku yang berakhir } \\
\text { pada } 31 \text { Desember selama tahun } 2015 \text { sampai } 2018 \text {. } \\
\text { Perusahaan non keuangan yang tidak menggunakan }\end{array}$ & (37) & $(111)$ \\
\hline $\begin{array}{l}\text { mata uang Rupiah dalam menyajikan laporan } \\
\text { keuangannya selama tahun } 2015 \text { sampai } 2018 \text {. }\end{array}$ & (64) & (192) \\
\hline $\begin{array}{l}\text { Perusahaan non keuangan yang tidak membagikan } \\
\text { dividen selama tahun } 2015 \text { sampai } 2018 \text {. }\end{array}$ & (90) & $(180)$ \\
\hline $\begin{array}{l}\text { Perusahaan non keuangan yang tidak memiliki } \\
\text { kepemilikan manajerial selama tahun } 2016 \text { sampai } 2018 .\end{array}$ & $(190)$ & $(520)$ \\
\hline $\begin{array}{l}\text { Perusahaan non keuangan yang tidak memiliki } \\
\text { kepemilikan institusional selama tahun } 2016 \text { sampai } \\
2018 \text {. }\end{array}$ & (5) & (15) \\
\hline Total perusahaan yang memenuhi kriteria sampel & 49 & 147 \\
\hline Data Outlier & & (4) \\
\hline Total perusahaan yang dijadikan sampel & & 143 \\
\hline
\end{tabular}

Sumber: Data Sampling

\section{Financial Distress merupakan}

variabel dependen dalam penelitian ini. Kazemian et al. (2017), financial distress dinilai menggunakan model Altman Z-Score. Altman ZScore menggunakan persamaan linear yang terbentuk dari beberapa variabel yang termasuk dalam skala rasio dan diwakili dengan huruf $X 1$, $X 2, X 3, X 4$ dan X5 dengan Z sebagai simbol pengganti untuk Financial Distress.

$Z=0.012 X 1+0.014 X 2+0.033 X 3+0.006 X 4+$ $0.999 \times 5$
Keterangan:

$\mathrm{X} 1$ = modal kerja neto $/$ total aset

$\mathrm{X} 2$ = saldo laba / total aset

X3 = Earning Before Interest and Taxes / total aset

X4 = nilai pasar terhadap ekuitas / total liabilitas

$X 5=$ penjualan $/$ total aset

$Z$ = indeks secara keseluruhan

Menurut Altman (1968), perusahaan dapat diklasifikasikan ke dalam 3 kelompok yaitu:

Tabel 2 Deskripsi Jarak Z-Score

No. Jarak dari Z-Score Deskripsi 


\begin{tabular}{|l|c|l|}
\hline 1. & Diatas 2,99 & $\begin{array}{l}\text { Kondisi keuangan berada dalam posisi yang baik dan } \\
\text { aman dari masalah keuangan. }\end{array}$ \\
\hline 2. & Antara 2,99 dan 1,81 & $\begin{array}{l}\text { Area ini dianggap abu-abu karena kondisi keuangan } \\
\text { memiliki peluang menghadapi masalah kebangkrutan. }\end{array}$ \\
\hline 3. & Kurang dari 1,81 & $\begin{array}{l}\text { Kondisi keuangan kemungkinan besar menuju } \\
\text { masalah kebangkrutan. Diperlukan tindakan untuk } \\
\text { menghindari situasi terburuk. }\end{array}$ \\
\hline
\end{tabular}

Sumber: Journal of International Studies (Kazemian et al. 2017)

Likuiditas adalah salah satu variabel penting dalam menentukan kemungkinan terjadinya financial distress. Hal ini dikarenakan level Likuiditas dapat mengindikasi level terjadinya kesulitan keuangan. Kazemian et al. (2017) menggunakan current ratio sebagai rumus pehitungan likuiditas.

$$
\text { Current Ratio }=\frac{\text { Current Assets }}{\text { Current Liabilities }}
$$

Leverage menjadi salah satu variabel yang patut diperhitungkan karena jika perusahaan mempunyai banyak hutang dan tidak mampu melunasinya, maka perusahaan tersebut dapat terjerumus ke dalam kesulitan keuangan. Pengukuran variabel Leverage pada penelitianKazemian et al. (2017) menggunakan perhitungan debt ratio dengan rumus sebagai berikut:

$$
\text { Debt Ratio }=\frac{\text { Total Debt }}{\text { Total Assets }}
$$

Profitabilitas adalah suatu pengukuran dari penghasilan atau income yang tersedia bagi pemilik perusahaan atas modal yang mereka investasikan di dalam perusahaan. Pengukuran variabel Profitabilitas pada penelitian Kazemian et al. (2017) menggunakan perhitungan profit margin dengan rumus sebagai berikut:

$$
\text { Profit Margin }=\frac{\text { Net Profit }}{\text { Total Sales }}
$$

Kinerja Perusahaan adalah kemampuan sebuah perusahaan untuk mengelola sumber daya yang ada sehingga dapat memberikan nilai kepada perusahaan tersebut. Pengukuran variabel Kinerja Perusahaan pada penelitian Kazemianet al. (2017) menggunakan pengukuran Tobin's $Q$ dengan rumus sebagai berikut:

Tobin's $Q=$

Market Value of Equity + Total Debt

Book Value of Assets

Menurut Bernardhi dan Muid (2014), rumus Market Value of Equity dapat dijabarkan sebagai berikut:

Market Value of Equity =

Closing Price x Total Outstanding Shares

Kebijakan Dividen adalah keputusan apakah laba perusahaan akan dibagikan kepada pemegang saham dalam bentuk dividen atau ditahan dalam bentuk laba sebagai pembiayaan investasi di masa yang akan datang. Pengukuran variabel Kebijakan Dividen pada penelitian Kazemian et al. (2017) menggunakan pengukuran dividend pay-out ratio (DPR) dengan rumus sebagai berikut:

$$
D P R=\frac{\text { Dividend per Share }}{\text { Earnings per Share }}
$$

Ukuran Perusahaan merupakan suatu perbandingan besar kecilnya suatu usaha dari suatu perusahaan. Pengukuran variabel Ukuran Perusahaan pada penelitian Rianti dan Winwinyadiati (2018) menggunakan rumus sebagai berikut:

$$
\text { Firm Size }=\text { Logarithm of Total Assets }
$$

Kepemilikan Manajerial dapat mempengaruhi kinerja manajemen. Hal ini dikarenakan manajer yang mempunyai suatu kepemilikan di suatu perusahaan mempunyai dorongan untuk 
meningkatkan kualitas perusahaan tersebut. Pengukuran variabel Kepemilikan Manajerial pada penelitian Anggraini (2016) menggunakan rumus sebagai berikut:

\section{Managerial Ownership =}

Shares Owned by Director and Manager

Total Outstanding Shares

Kepemilikan Institusional adalah kepemilikan jumlah saham perusahaan oleh lembaga keuangan seperti perusahaan reksa dana, perusahaan dana pensiun dan perusahaan non bank lainnya dimana lembaga tersebut mengelola dana atas nama orang lain. Pengukuran variabel Kepemilikan Institusional pada penelitian Anggraini (2016) menggunakan rumus sebagai berikut:

Institutional Ownership =

\section{Shares Owned by Institutions \\ Total Outstanding Shares}

Pengujian ini menggunakan metode analisis regresi berganda dengan tingkat kesalahan yang dapat ditolerir adalah 5\%. Persamaan linear terbentuk sebagai berikut:

$F D=\beta 0+\beta 1 C R+\beta 2 D R+\beta 3 N P M A R G I N+$ $\beta 4$ TOBIN'SQ $+\beta 5 \mathrm{DPR}+\beta 6 \mathrm{SIZE}+\beta 7 \mathrm{MO}+$ $\beta 810+\varepsilon$

\section{HASIL DAN PEMBAHASAN}

Statistik deskriptif data penelitian dapat dilihat pada tabel 3. Variabel dependen Financial Distress (FD) mempunyai nilai minimum sebesar 0,07765 dan nilai maksimum sebesar 2,89245 dengan nilai mean sebesar 0,99217 dan nilai deviasi standar sebesar 0,58209. Selain itu, 8 variabel independen lainnya memiliki nilai minimum, maksimum, mean, dan deviasi standar yang berbeda-beda sesuai dengan tabel 3.

Tabel 3 Statistik Deskriptif

\begin{tabular}{lrrrr}
\hline \multicolumn{1}{c}{ Variabel } & \multicolumn{1}{c}{ Minimum } & \multicolumn{1}{c}{ Maksimum } & \multicolumn{1}{c}{ Mean } & \multicolumn{1}{c}{$\begin{array}{c}\text { Std. } \\
\text { Deviation }\end{array}$} \\
\hline FD & 0,07765 & 2,89245 & 0,99217 & 0,58209 \\
CR & 0,38009 & 15,16460 & 2,46518 & 2,00627 \\
DR & 0,07497 & 0,81081 & 0,42649 & 0,18530 \\
NP MARGIN & $-0,25732$ & 0,46964 & 0,10867 & 0,10466 \\
TOBIN'S Q & 0,46282 & 9,70124 & 1,88028 & 1,48908 \\
DPR & 0,04313 & 2,57732 & 0,41433 & 0,28942 \\
SIZE & 11,20419 & 14,53746 & 12,79571 & 0,75339 \\
MO & 0,00000 & 0,42936 & 0,05898 & 0,10628 \\
IO & 0,13968 & 0,94197 & 0,60351 & 0,16826 \\
\hline
\end{tabular}

Sumber: Hasil output statistik

Tabel 4 Hasil Uji Multikolinearitas 


\begin{tabular}{lcc}
\hline \multicolumn{1}{r}{ Variabel } & Tolerance & VIF \\
\hline CR & 0,437 & 2,290 \\
DR & 0,378 & 2,644 \\
NPMARGIN & 0,599 & 1,669 \\
TOBIN'S Q & 0,634 & 1,578 \\
DPR & 0,708 & 1,413 \\
SIZE & 0,715 & 1,398 \\
MO & 0,646 & 1,547 \\
IO & 0,669 & 1,496
\end{tabular}

Sumber: Hasil output statistik

Tabel 5 Hasil Uji t

\begin{tabular}{ccc}
\hline Variabel & B & Sig. \\
\hline (Constant) & 3,519 & 0,000 \\
CR & $-0,36$ & 0,218 \\
DR & 0,264 & 0,439 \\
NPMARGIN & $-3,078$ & 0,000 \\
TOBIN'S Q & 0,237 & 0,000 \\
DPR & $-0,307$ & 0,056 \\
SIZE & $-0,188$ & 0,002 \\
MO & $-0,907$ & 0,048 \\
IO & $-0,127$ & 0,651 \\
\hline
\end{tabular}

Varaibel dependen: Financial distress

Adj $R^{2}$ 0,371, F8,134 11,479 Sig. 0,000

Sumber: Hasil output statistik

Hasil uji multikolinearitas dapat dilihat pada tabel 4. Seluruh variabel tidak terjadi multikolinearitas karena seluruh variabel independen masing-masing memiliki nilai tolerance di atas 0,1 dan nilai VIF di bawah 10 . Artinya, tidak terdapat hubungan antar variabel independen sehingga seluruh data baik digunakan dalam penelitian. Hasil uji autokorelasi nilai sig. pada res_2 sebesar 0,154 lebih tinggi dari nilai alpha $(\alpha=0,05)$ yang berarti bahwa tidak terjadi autokorelasi sehingga data baik digunakan dalam penelitian.

Hasil analisis koefisien determinasi menunjukkan bahwa nilai Adjusted $R$ Square sebesar 0,371. Artinya, secara statistik besarnya variasi variabel dependen (Financial
Distress) yang dapat dijelaskan oleh variasi variabel independen (Likuiditas, Leverage, Profitabilitas, Kinerja Perusahaan, Kebijakan Dividen, Ukuran Perusahaan, Kepemilikan Manajerial, dan Kepemilikan Institusional) adalah sebesar $37,1 \%$ sedangkan sisanya sebesar $62,9 \%$ dijelaskan oleh variasi variabel lain yang tidak dimasukkan ke dalam model regresi. Hasil uji $F$ menunjukkan bahwa Sig. mempunyai nilai lebih kecil dari alpha $(\alpha=0,05)$ yang berarti model fit atau layak digunakan dalam penelitian.

Hasil uji $t$ mendapatkan beberapa kesimpulan yang berbeda. Likuiditas (CR) memiliki nilai koefisien sebesar $-0,30$ yang menunjukkan arah koefisien negatif dan nilai sig. 
sebesar 0,218 lebih besar dari alpha $(\alpha=0,05)$, maka $\mathrm{H}_{1}$ tidak dapat diterima. $\mathrm{Hal}$ ini menunjukkan bahwa Likuiditas tidak berpengaruh terhadap terjadinya Financial Distress.

Leverage (DR) memiliki nilai koefisien sebesar 0,264 yang menunjukkan arah positif dan nilai sig. sebesar 0,439 lebih besar dari alpha $(\alpha=0,05)$, maka $\mathrm{H}_{2}$ tidak dapat diterima. Hal ini menunjukkan bahwa leverage tidak berpengaruh terhadap terjadinya Financial Distress.

Profitabilitas (NPMARGIN) memiliki nilai koefisien sebesar -3,078 yang menunjukkan arah koefisien negatif dan nilai sig. sebesar 0,000 lebih kecil dari alpha $(\alpha=0,05)$, maka $\mathrm{H}_{3}$ dapat diterima. Hal ini menunjukkan bahwa profitabilitas berpengaruh terhadap terjadinya Financial Distress. Hasil ini sesuai dengan hasil penelitian Kazemian et al. (2017), Finishtya (2019), Masdupi et al. (2018), Jaafar et al. (2018), Dance dan Made (2019), dan Widarjo dan Setiawan (2009). Perusahaan dengan net margin yang tinggi akan menurunkan angka zscore dari Financial Distress sehingga risiko terjadinya Financial Distress naik. Profitabilitas yang semakin baik biasanya akan diikuti dengan tekanan beban yang lebih besar dari pihak internal maupun eksternal. Jika perusahaan tidak mampu menutupi tekanan beban tersebut, maka kemungkinan terjadinya Financial Distress menjadi lebih tinggi.

Kinerja Perusahaan (TOBIN'S Q) memiliki nilai koefisien sebesar 0,237 yang menunjukkan arah koefisien positif dan nilai sig. sebesar 0,000 lebih kecill dari alpha $(\alpha=0,05)$, maka $\mathrm{H}_{4}$ dapat diterima. Hal ini menunjukkan bahwa Kinerja Perusahaan berpengaruh terhadap terjadinya Financial Distress. Hasil ini sesuai dengan hasil penelitian Kazemian et al. (2017), Bisogno dan De Luca (2012), dan Pindado dan Rodrigues (2005). Kinerja Perusahaan yang semakin baik akan meningkatkan angka z-score dari Financial Distress sehingga risiko terjadinya Financial
Distress turun. Kinerja yang tinggi menunjukkan bahwa perusahaan mampu memenuhi harapan para pemegang saham yang menginginkan keuntungan yang tinggi. Angka keuntungan yang tinggi dalam laporan keuangan akan menarik minat para calon investor dalam menanamkan modalnya, sehingga Financial Distress dapat terhindari.

Kebijakan Dividen (DPR) memiliki nilai koefisien sebesar -0,307 yang menunjukkan arah koefisien negatif dan nilai sig. sebesar 0,056 lebih besar dari alpha $(\alpha=0,05)$, maka $\mathrm{H}_{5}$ tidak dapat diterima. Hal ini menunjukkan bahwa Kebijakan Dividen tidak berpengaruh terhadap terjadinya Financial Distress.

Ukuran Perusahaan (SIZE) memiliki nilai koefisien sebesar $-0,188$ yang menunjukkan arah koefisien negatif dan nilai sig. sebesar 0,002 lebih kecil dari alpha $(\alpha=0,05)$, maka $\mathrm{H}_{6}$ dapat diterima. Hal ini menunjukkan bahwa Ukuran Perusahaan berpengaruh terhadap terjadinya Financial Distress. Hasil ini sesuai dengan hasil penelitian Rianti dan Winwinyadiati (2018). Semakin besar Ukuran Perusahaan maka akan menurunkan angka zscore dari Financial Distress yang berarti risiko terjadinya Financial Distress naik. Total aset perusahaan secara tidak langsung mencerminkan ukuran perusahaan itu sendiri. Semakin besarnya total aset, maka beban yang timbul juga akan semakin besar. Beban yang semakin besar akan mengurangi keuntungan perusahaan. Di sisi lain, tidak semua calon investor melihat perusahaan yang besar sebagai tempat yang tepat untuk ditanamkan modal. Beberapa tipe investor lebih senang menanamkan modal di perusahaan yang lebih kecil karena mereka dapat membeli saham yang lebih besar dan mendapatkan dividen yang tinggi.

Kepemilikan Manajerial (MO) memiliki nilai koefisien sebesar $-0,907$ yang menunjukkan arah koefisien negatif dan nilai sig. sebesar 0,048 lebih kecil dari alpha $(\alpha=0,05)$, maka $\mathrm{H}_{7}$ dapat diterima. Hal ini menunjukkan 
bahwa Kepemilikan Manajerial berpengaruh terhadap terjadinya Financial Distress. Hasil ini sesuai dengan hasil penelitian Maryam dan Yuyetta (2019). Semakin besar Kepemilikan Manajerial maka akan menurunkan angka zscore dari Financial Distress yang berarti risiko terjadinya financial distress naik. Jika manajer memiliki porsi kepemilikan di perusahaan, manajer mempunyai akses lebih besar terhadap informasi penting dalam perusahaan. Perbedaan informasi yang didapatkan oleh pemegang saham dan manajer akan menimbulkan konflik. Konflik yang muncul menyebabkan beban yang lebih besar terhadap perusahaan.

Kepemilikan Institusional (IO) memiliki nilai koefisien sebesar-0,127 yang menunjukkan arah koefisien negatif dan nilai sig. sebesar 0,651 lebih besar dari alpha $(\alpha=0,05)$, maka $\mathrm{H}_{8}$ tidak dapat diterima. Hal ini menunjukkan bahwa Kepemilikan Institusional tidak berpengaruh terhadap terjadinya Financial Distress.

\section{PENUTUP}

Berdasarkan hasil penelitian yang dilakukan, dapat disimpulkan bahwa hanya beberapa hipotesis alternatif yang dapat diterima. Profitabilitas, Kinerja Perusahaan, Ukuran Perusahaan, dan Kepemilikan
Manajerial menunjukkan hasil berpengaruh terhadap terjadinya Financial Distress. Likuiditas, Leverage, Kebijakan Dividen, dan Kepemilikan Institusional menunjukkan hasil tidak berpengaruh terhadap terjadinya Financial Distress.

Keterbatasan penelitian ini yaitu, periode penelitian yang relatif singkat yaitu hanya 3 tahun, penelitian hanya menggunakan 8 variabel independen yang diperkirakan masih terdapat variabel independen lain yang dapat mempengaruhi terjadinya Financial Distress, penelitian tidak menggunakan klasifikasi spesifik (perusahaan yang memiliki laba bersih negatif atau tidak memiliki keuntungan berturut-turut selama 3 tahun terakhir selama terdaftar di Bursa Efek Indonesia) sehingga sebaran data menjadi lebih luas.

Dengan

mempertimbangkan keterbatasan yang telah disebutkan di atas, maka penulis memberikan beberapa saran untuk penelitian selanjutnya. Pertama, periode penelitian dapat ditambahkan agar hasil lebih relevan dan akurat. Kedua, menambah variabel independen lain, seperti Pertumbuhan Perusahaan, Board Size, Board Independent, dan lainnya. Ketiga, penelitian selanjutnya dapat menggunakan metode pengukuran variabel dependen lain selain Altman Z-Score (seperti metode Springate dan metode Zmijewski).

\section{REFERENCES:}

Altman, L. Edward dan Edith Hotchkiss. 2005. Corporate Financial Distress and Bankruptcy: Predict and Avoid Bankruptcy, Analyze and Invest in Distress Debt, 3rd Edition. New York: John Wiley \& Sons Inc.

Anggraini, Dewi. 2016. Financial Distress Model Prediction for Indonesian Companies. International Journal of Management and Administrative Sciences, 3(4), 74-84.

Bernandhi, Riza dan Abdul Muid. 2014. Pengaruh Kepemilikan Manajerial, Kepemilikan Institusional, Kebijakan Dividen, Leverage, dan Ukuran Perusahaan Terhadap Nilai Perusahaan. Diponegoro Journal of Accounting, 3(1), 1-14.

Bisogno, Marco dan Roberto De Luca. 2012. Indirect Costs of Bankruptcy: Evidence From Italian SMES. Journal of Accounting and Finance, 2(1), 20-30.

Dance, Mesak dan Sukartha I Made. 2019. Financial Ratio Analysis in Predicting Financial Conditions Distress in Indonesia Stock Exhange. Russian Journal of Agricultural and Sosio-Economic Sciences, 2(86), 155165. 
Dwijayanti, S. Patricia Febrina. 2010. Penyebab, Dampak, dan Prediksi dari Financial Distress Serta Solusi Untuk Mengatasi Financial Distress. Jurnal Akuntansi Kontemporer, 2(2), 191-205.

Fahlevi, Muhammad Reza dan Aan Marlinah. 2018. The Influence of Liquidity, Capital Structure, Profitability and Cash Flows on The Company's Financial Distress. Jurnal Bisnis dan Akuntansi, 20(1), 59-68.

Fahmi, Irham. 2010. Manajemen Kinerja: Teori dan Aplikasi. Bandung: Alfabeta.

Finishtya, Florentina Cindy. 2019. The Role of Cash Flow of Operational, Profitability, and Financial Leverage in Predicting Financial Distress on Manufacturing Company in Indonesia. Journal of Applied Management, 17(1), 110-117.

Ibrahim, Rahmasari. 2019. Corporate Governance Effect on Financial Distress: Evidence From Indonesian Public Listed Companies. Journal of Economics, Business, and Accountancy Ventura, 21(3), 415-422.

Idarti dan Afriyanti Hasanah. 2018. Analisis Pengaruh Struktur Kepemilikan, Kebijakan Hutang dan Likuiditas Terhadap Financial Distress. Journal of Applied Managerial Accounting, 2(2), 160-178.

Jaafar, Mohamad Nizam, Amirul Afif Muhamat, Sharifah Faigah Syed Alwi, Norzitah Abdul Karim, Syafini binti A. Rahman. 2018. Determinants of Financial Distress among the Companies Practise Note 17 Listed in Bursa Malaysia. International Journal of Academic Research in Business and Social Sciences, 8(11), 798-809.

Kazemian et al. 2017. Monitoring Mechanism and Financial Distress of Public Listed Companies in Malaysia. Journal of International Studies, 10(1), 92-109.

Khurshid, Muhammad Kashif, Hazoor Muhammad Sabir, Safdar Hussain Tahir, Muhammad Abrar. 2018. Impact of Corporate Governance on the Likelihood of Financial Distress: Evidence from Non-Financial Firms of Pakistan. Pacific Business Review International, 11(4), 134-149.

Lestari, Henny Setyo dan Fardini Rahma Dewi. 2013. Pengaruh Growth dan Financial Strength Terhadap Financial Distress. Jurnal Bisnis dan Akuntansi, 15(2), 187-199.

Mafiroh, Anis dan Triyono. 2016. Pengaruh Kinerja Keuangan dan Mekanisme Corporate Governance Terhadap Financial Distress. Riset Akuntansi dan Keuangan Indonesia, 1(1), 46-53.

Maryam dan Etna Nur Afri Yuyetta. 2019. Analisis Pengaruh Mekanisme Corporate Governance Terhadap Probabilitas Terjadinya Financial Distress. Diponegoro Journal of Accounting, 8(3), 1-11.

Masdupi, Erni, Abel Tasman dan Atria Davista. 2018. The Influence of Liquidity, Leverage and Profitability on Financial Distress of Listed Manufacturing Companies in Indonesia. Advances in Economic, Business and Management Research, 57, 223-228.

Mawutor, John Kwaku Mensah. 2014. The Failure of Lehman Brothers: Causes, Preventive Measures and Recommendations. Research Journal of Finance and Accounting, 5(4), 85-91.

Octalianna dan Deasy Ariyanti Rahayuningsih. 2013. Analisis Kepemilikan Managerial Berbasis Pada Teori Keagenan. Jurnal Bisnis dan Akuntansi, 15(1), 65-72.

Permanasari, Meiryananda. 2017. Faktor-Faktor yang Mempengaruhi Kebijakan Dividen pada Perusahaan Non Keuangan di Indonesia. Jurnal Bisnis dan Akuntansi, 19(1), 27-37.

Pindado, Julio dan Luis Rodrigues. 2005. Determinants of Financial Distress Costs. Financial Markets and Portfolio Management, 19(4), 343-359.

Prasetyo, Rifky Adhi dan Fachrurrozie. 2016. Analysis of Factors Effecting on The Profitability of Financial Distress. Accounting Analysis Journal, 5(4), 370-380.

Rianti, Inten Puji dan Winwinyadiati. 2018. The Influence Firm Size on Financial Distress: A Research on Agricultural Companies Listed in Indonesia Stock Exchange. International Business Management, 12(4), 365-369.

Saputri, Lilis dan Asrori. 2019. The Effect of Leverage, Liquidity and Profitability on Financial Distress with the Effectiveness of the Audit Committee as a Moderating Variable. Accounting Analysis Journal, 8(1), 3844.

Sastriana, Dian dan Fuad. 2013. Pengaruh Corporate Governance dan Firm Size Terhadap Perusahaan yang Mengalami Kesulitan Keuangan (Financial Distress). Diponegoro Journal of Accounting, 2(3), 1-10. 
Tamam, Dede Badru dan Satriyo Wibowo. 2017. Pengaruh Tangibility, Profitability, Liquidity, Firm Size dan Non Debt Taxshield Terhadap Capital Structure Pada Sektor Pertanian. Jurnal Bisnis dan Akuntansi, 19(1), 129-135.

Widarjo, Wahyu dan Doddy Setiawan. 2009. Pengaruh Rasio Keuangan Terhadap Kondisi Financial Distress Perusahaan Otomotif. Jurnal Bisnis dan Akuntansi, 11(2), 107-119.

Widhicahyono, Sigit dan Bambang Sudiyatno. 2015. Determinan Kebijakan Dividen Perusahaan Non Keuangan (Studi Bursa Efek Indonesia Tahun 2009-2013). Jurnal Bisnis dan Ekonomi (JBE), 22(2), 171-187

Widiasmara, Anny dan Henny Catur Rahayu. 2019. Perbedaan Model Ohlson, Model Taffler dan Model Springate Dalam Memprediksi Financial Distress. Inventory: Jurnal Akuntansi, 3(2), 141-158

Witiastuti, Rini Setyo dan Dhini Suryandari. 2016. The Influence of Good Corporate Governance Mechanism on the Possibility of Financial Distress. Review of Integrative Business and Economics Research, 5(1), 118-127. 